\title{
TOLERANSI KEAGAMAAN MASYARAKAT DI DESA GUWA LOR KECAMATAN KALIWEDI KABUPATEN CIREBON
}

\section{COMMUNITY RELIGIOUS TOLERANCE IN GUWA LOR VILLAGE, KALIWEDI DISTRICT CIREBON}

\author{
Akhsin Ridho \\ Institut Agama Islam Negeri Jember, Indonesia \\ psi.iain.jember@gmail.com \\ Artikel diterima 7 November 2019, diseleksi 11 November 2020, dan disetujui 12 \\ Desember 2020
}

\begin{abstract}
The study, which begins with the existence of differences in religious rituals in rural areas, a tradition that is maintained from time to time, is tolerant, religious, and inclusive aims to determine the process of forming harmony in different communities in religious understanding. Religious spirit is an important reason for this research, which is researched using descriptive qualitative methods through observation of the role of religious leaders who are randomly selected in the phenomenological research area. In this study, it was found that there was a strong interaction between religious leaders and the community through messages to maintain mutual attitudes and speech was the key to establishing a harmonious relationship. The practice of different religious rituals for society is common. These differences are found at the level of branching, not in the main things such as tahlilan, syukuran, mapag sri, sedekah bumi, selametan and other religious rituals. It can be concluded that the role models of religious figures are the main key to maintaining harmony in the life of religious communities. They provide direct demands on attitudes and actions in society. They educate the community which is internalized through actions on religious practices that are assimilated in customs, culture and rituals related to the needs of religious communities in rural communities and provide new knowledge for the community to maintain mutual religious harmony, side by side in diversity.
\end{abstract}

\begin{abstract}
Abstrak
Kajian yang bermula dari adanya perbedaan ritual keagamaan di pedesaan, tradisi yang terjaga dari masa ke masa, toleran, religius, dan inklusif ini bertujuan untuk mengetahui proses terbentuknya kerukunan dalam masyarakat yang berbeda dalam paham keagamaan. Spirit keagamaan menjadi alasan penting dari penelitian ini, penelitian menggunakan metode kualitatif deskriptif melalui observasi pada peran tokoh agama yang dipilih secara acak pada wilayah Desa Guwa Lor Kecamatan Kaliwedi, Cirebon. Dalam kajian ini ditemukan adanya interaksi yang kuat antar tokoh agama dengan umat melalui pesan untuk saling menjaga sikap dan tutur kata menjadi kunci terjalinnya hubungan yang harmonis. Praktik ritual keagamaan yang berbeda bagi masyarakat merupakan hal biasa. Perbedaan tersebut ditemukan pada tataran percabangan bukan pada hal pokoknya seperti tahlilan, syukuran, mapag sri, sedekah bumi, selametan dan ritual keagamaan lainnya. Disimpulkan bahwa keteladanan tokoh agama menjadi kunci utama terjalinnya harmoni kehidupan umat beragama, mereka memberikan tuntutan dalam sikap dan perbuatan secara langsung di masyarakat. Mereka mengedukasi masyarakat yang diinternalisasikan melalui perbuatan pada praktik keagamaan yang diasimilasikan dalam adat, budaya dan ritual yang berhubungan dengan kebutuhan umat beragama di masyarakat pedesaan serta memberikan pengetahuan baru bagi masyarakat untuk saling menjaga kerukunan hidup beragama, berdampingan dalam keragaman.
\end{abstract}


Keywords: religious practice, tolerance, religious figures

\section{PENDAHULUAN}

Masyarakat membutuhkan jaminan kemerdekaan dalam memeluk agama dan kepercayaan sesuai dengan apa yang diyakini tanpa ancaman dari siapa pun, mereka juga berhak untuk menjalankan ibadah sesuai dengan keyakinannya tersebut dengan aman tanpa ada gangguan dari siapa pun tetapi ada batasan bahwa hal tersebut tidak boleh mengusik keyakinan orang lain (Abdullah, 2011).

Kebebasan menjalankan ritual keagamaan ini berlaku untuk siapa saja tanpa memerdulikan suku, dan asal daerah, tanpa takut ada diskriminasi oleh siapa pun terlebih lagi bagi warga negara yang hidup di Negara yang banyak memiliki perbedaan agama, suku bangsa dan kebudayaan. Kemajemukan tersebut bisa memicu konflik laten bila kerukunan yang tidak terjaga dengan baik (Maknun, 2020).

Masyarakat yang tinggal bersama pemelukagamayangberbedamemerlukan jaminan kenyamanan dalam menjalankan keyakinannya tanpa diganggu oleh siapa pun dalam hal keyakinan tersebut. Hubungan hanya terkait dengan masalah aqidah dan ibadah, sehingga masyarakat tetap bersikap inklusif, pergaulan dan hubungan sosial dengan pemeluk agama lain tidak saling mengganggu (Hasyim, 2015).

Keragaman masyarakat yang berbeda-beda namun tetap selaras menjaga hubungan dengan sesamanya, menjaga asimilasi budaya lewat internalisasi sesuai dengan karakter masyarakat dan tidak bertolak belakang dengan agama serta mampu memberi manfaat bagi masyarakat. Budaya yang diadopsi untuk mengelolah kebersamaan
Kata Kunci: praktik keagamaan, toleransi, tokoh agama

masyarakat baik berasal dari kebudayaan asli atau serapan yang bersifat primordial (Iswanto \& Hasiholan Hutapea, 2019).

Interaksi di atas kadangkala menimbulkan efek positif bagi keberlangsungan kerukunan antarumat beragama, namun disisi lain hal tersebut menjadi duri dalam daging ketika tidak bisa dikelola dengan baik terlebih bila konflik tersebut menyulut identitas agama maupun suku seperti di Indonesia yang berpenduduk majemuk dan memiliki ciri khas masing-masing dalam berbagai adat maupun budaya (Baharudin \& Luthfan, 2017).

Pelanggaran kebebasan beragama dan berkeyakinan di Indonesia naik sebesar 23\% (Wardah, 2019). Hal ini berdasarkan temuan dari The Wahid Institut sebanyak 190 kasus (The Wahid, 2014) Imparsial melaporkan terjadi sebanyak 31 kasus (Setiawan, 2019). Pelanggaran yang sering terjadi adalah soal pendirian, perusakan, pelarangan, penghalangan dan gangguan kegiatan keagamaan serta kekerasan atas nama agama (Ridho, 2018).

Kebebasan beragama dan berkeyakinan yang dilanggar berbanding terbalik dengan fungsi agama yang mengajarkan pesan kebaikan, kedamaian, serta keselarasan hidup pada pemeluknya, baik dengan sesama dan makhluk-Nya yang lain (Saihu, 2020). Mengajarkan kedamaian bagi alam semesta. Fenomena keragaman agama dalam 300 lebih etnis di Indonesia merupakan fakta dan realitas nyata dihadapi bangsa Indonesia, maka kesadaran beragama harus terus dikembangkan sebagai fitrah kehidupan manusia untuk saling menghargai perbedaan (Haryani, 2019). 
Kesadaran pentingnya kerukunan beragama dan adanya struktur sosial yang adil sebagai bentuk ekspresi beragama yang timbul dari keyakinan antar agama di masyarakat mampu memunculkan peran agama sebagai ikatan sosial dalam arti yang luas. Adanya agama yang berbeda merupakan fenomena yang nyata dan tidak dapat dielakkan dalam kebutuhan hidup masyarakat. Kemajemukan menjadi rahmat untuk disyukuri, akan tetapi menjadi suatu tantangan tersendiri bagi hubungan umat beragama sehingga tidak boleh menghilangkan empati kita sebagai umat beragama (Panuntun \& Paramita, 2020).

Adanya agama yang berbeda merupakan sesuatu yang tidak dapat ditolak keberadaanya di manapun, kapanpun dan oleh siapa pun. Perbedaan itu memunculkan adanya pluralisme agama, namun bukan pada tataran ibadah sehingga pengertian ini berbeda dengan definisi yang dikeluarkan oleh Majelis Ulama Indonesia di mana ditegaskan bahwa pluralisme agama adalah suatu paham yang ditolak karena menyamakan suatu agama yang satu dengan agama yang lainnya (Majelis Ulama Indonesia, 2005).

Pluralitas tersebut bukan hanya soal agama tetapi menyangkut pada aspek kehidupan ekonomi dan sosial masyarakat. Ruang dalam dunia global yang tidak lagi ada batas-batas geografis dan budaya mengubah seluruh aspek dan sendi-sendi kehidupan manusia menjadi bebas, komoditas yang menuntut adanya kesadaran penuh dari setiap warga terhadap adanya pluralitas semakin meningkat, khususnya agama yang dianut oleh masyarakat, hal ini sebagai upaya aktif untuk memahami perbedaan keyakinan (Setyabudi, 2019).

Pergulatan budaya yang beragam dipengaruh oleh kultur masyarakat plural kemudian direkontruksi oleh kesadaran dan sejarah masyarakat, dipadukan dengan penerapan etika-etika atau kesepakan yang tumbuh di masyarakat (Maknun, 2020). Sedangkan pengaruh agama ikut memengaruhi seluruh setting tingkah laku, ritual keagamaan, dan religiusitas masyarakatnya, memberikaan kompleksitas warna tersendiri bagi perkembangan dinamisasi sosial masyarakat (Fatoni, 2020).

Situasi kerukunan umat beragama di masyarakat lokal sebenarnya bisa digunakan sebagai laboratorium untuk melanjutkan perdebatan lama: apakah peran Agama lebih disebabkan oleh determinasi struktur atau oleh faktor non-keagamaan, khususnya kebudayaan. Situasi tersebut memberi gambaran terhadap pola interaksi masyarakat dalam adaptasi yang membentuk sikap toleran (Arifin. dkk., 2004).

Subjek yang menonjol yang menyebabkan penelitian ini berbeda denganpenelitianlainnyaadalahspiritdari potret masyarakat pedesaan yang terlibat dalam membangun keteladanan sikap toleran terhadap perbedaan. Sebagian masyarakat sebenarnya tidak terlalu mendalam akan pemahaman agamanya, namun semangat keagamaannya yang toleran, kebersamaan dalam kegiatan sosial kemasyarakat, dan keunggulan perilaku sosial yang acapkali dianggap membedakan dengan masyarakat lainnya, khususnya dalam keuletannya menjaga hubungan sosial dan daya tahannya dalam menghadapi problemproblem sosial lainnya menjadi daya tarik sendiri untuk diteliti.

Semangat solidaritas masyarakat, khususnya pada kelompok aliran dan paham yang berbeda, seringkali tidak hanya terbatas dalam penegasan identitas, etnisitas dan semangat keagamaan, yang hampir tidak memiliki implikasi dalam dunia kegiatan yang mereka lakukan. 
Kebanggaannya atas komunitasnya sendiri, tidak hanya berfungsi sebagai terminal sementara, tetapi juga menjadi awal rasa aman yang agak imitatif dan kosong dari semangat religius.

Masjid menjadi lembaga pertama yang digunakan tokoh agama dalam kebutuhan awal untuk beradaptasi menyebarkan toleransi beragama. Ketergantungannya pada keagamaan dan pengalamannya dalam memperjuangkan kebutuhan ibadah umat, tokoh agama ikut mewarnai persepsi tentang kebersamaan yang dibutuhkan. Timbulnya empati yang memadai berupa keinginan untuk hidup berdampingan dengan orang lain dan kesamaan pandangan dalam corak beragama dan berkeyakinan, tidak sekadar memperlebarkewajiban sosialnya tetapi juga didasari oleh semangat bahwa perbedaan itu menjadi sesuatu hal yang wajar (Umam \& Ghazali, 2019).

Penelitian ini bertujuan untuk mengurai ruang toleransi khususnya mengenai kondisi dan praktik keagamaan masyarakat di pedesaan. pertanyaan mendasar dari rumusan masalah pada objek penelitian adalah bagaimana kerukunan umat beragama terbentuk, ketika posisi ini dipahami sebagai masyarakat yang homogen namun berbeda pandangan dalam paham keagamaannya. Ringkasnya bagaimana keterlibatan masyarakat dalam mengelolah kemajemukan yang memiliki beragam cara beragama.

Kajian ini dimulai dengan peran tokoh agama dalam membina perilaku sosial masyarakat dan fungsi lembagalembaga keagamaan dalam menguatnya toleransi, semangat untuk melakukan kerja sama dan hidup berdampingan dengan dengan masyarakat yang berbeda dalam hal ritual keagamaan.

Hipotesis sementara penelitian ini adalah "kegiatan masyarakat masih terikat oleh nilai-nilai sosial budaya lokal, kegiatan tersebut sepenuhnya mengikuti mekanisme yang dicontohkan pemuka agama dengan diperkuat oleh posisi agama sebagai penggerak dan motivasi utamanya." Sebab, "budaya bukanlah sebuah kenyataan sosial yang sudah selesai, namun terinternalisasi oleh subjek-subjek budaya yang pasif.

Budaya lokal bukanlah hal yang sama seperti subjektivitas individu dan bukan satu-satunya hal yang memengaruhi minat, pertimbangan dan watak seseorang namun ada peran dan legitimasi dari tokoh agama yang berpengaruh terhadap masyarakat. Bahkan ketika ada fatwa, masyarakat akan patuh walaupun dari lingkungan yang berbeda, masyarakat tetap berpegang pada anjuran tokoh agama dan mereka tetap menerapkan tradisinya dalam berbagai cara yang berlainan bahkan bisa bertentangan (Hefner, 1987).

Tokoh agama membangun persepsi kebebasan beragama di masyarakat melalui upaya dialog dan pendidikan dalam merepleksiannya. Internalisasi yang terbangun tidak serta merta terbentuk namun merupakan proses perjuangan panjang dan berliku. Proses ini terus dipertahankan sehingga terbentuk masyarakat yang mapan dalam beragama, tidak mudah diprovokasi ataupun dihasut untuk membenci agama orang lain.

Pendekatan dikotomis tidak seluruhnya bisa digunakan sebagai analisis tunggal, mengingat masalah ini tidak secara hitam-putih dapat ditarik garis-batasnya. Harus diakui posisi tulisan ini akan banyak menggambil porsi tradisi neo-Weberian, dalam arti adanya keinginan untuk melihat korelasi antara kegiatan keagamaan dengan kebudayaan. Namun, semangat itu sama sekali tidak ingin mengambil posisi yang agak membabi buta seperti umumnya kelompok essensialis, yang terlalu berlebihan menggambarkan determinasi 
kebudayaan yang serba linear, deterministik dan bersifat universal (Watloly, 2001).

Peter L. Berger mengatakan bahwa konsensus dan konflik selalu melekat bersama-sama di dalam setiap kehidupan sosial (Dhohiri, 2003). Integrasi akan timbul karena adanya orientasi antar elemen sosial memiliki perasaan dalam kelompok terhadap kelompoknya dan ada kelompok lain di luar kelompoknya (M. Setiadi \& Kolip, 2013). Manusia dalam perkembangan sosiologi menjadi dua objek kajian penting yaitu sebagai individu atau masyarakat. Konsepsi tersebut menjadi starting poin adanya paradigma plural walaupun berbeda namun keduanya menjadi penjelas dari objek lainnya.

Perbedaan pandangan pada objek manusia sebagai wilayah kajian ini memiliki nilai subjektive world terutama bagi kalangan pluralis yang memandang masalah bukan menjadi benalu atau penyakit yang harus dimusnahkan tetapi menjadi realitas dari kondisi sosial masyarakat itu sendiri. Hal tersebut dikaitkan pada proses interaksi masyarakat yang bermula dari adanya gagasan, peraturan dan hukum yang dibuat bersama.

Berdasarkan konteks di atas khususnya tentang keberadaan umat yang berbeda paham atau aliran, keyakinan atau mazhab dalam beragama, kontribusi pembentukan peradaban masyarakat dan pengelolahan kemajemukan sehingga dalam rangkaian sejarah tersebut terlihat bagaimana sumbangsih dan perannya atas konstruksi sosial-keagamaan yang ada dengan harapan dapat memberikan gambaran penting tentang komplektisitas proses edukasi pemahaman toleransi kehidupan beragama yang berdampak pada pemahaman masyarakat akan pentingnya toleransi agama untuk menciptakan keharmonisan pada kerukunan hidup beragama serta langkah pencegahan terhadap gejala paham radikalisme di masyarakat.

\section{METODE}

Metode kualitatif digunakan dalam prosedur penelitian ini dengan menggunakan analisis deskriptif bersumber dari data lapangan pada wilayah kajianyang telah diteliti(Moleong, 2007). Menggunakan pendekatan ekploratif, untuk menemukan jawaban atas rumusan masalah dari fenomena kemudian diafirmasi, dikupas dan diselidiki secara ajek melalui kegiatan observasi di lapangan penelitian melalui wawancara dengan tokoh masyarakat dan masyarakat yang dipilih secara acak. (Arikunto, 2002).

Penelitian ini difokuskan pada kajian toleransi keagamaan masyarakat pedesaan di Desa Guwa Lor Kecamatan Kaliwedi Kabupaten Cirebon Provinsi Jawa Barat dan dilaksanakan dari bulan Juli 2020 sampai dengan Oktober 2020 kaitannya dengan peran tokoh agama yang menjadi subjek penelitian dalam mengelolah toleransi kehidupan keagamaan masyarakat, menggunakan metode deskriptif yang berupaya untuk memperdalam perolehan data dan mempertajam analisis data tersebut secara mendalam pada aspek lingkungan sosial terhadap individu, kelompok dan lembaga (Nawawi, 2007).

Proses ini sesuai dengan tujuan, sifat dan pendekatan penelitian yang digunakan, pengumpulan data utama dilakukan melalui observasi, wawancara mendalam dan studi dokumentasi (Narbuko \& Ahmadi, 2001). Narasumber atau partisipan ditentukan secara purposif. Analisis induktif digunakan dalam penelitian kualitatif ini berdasarkan suatu analisis data yang diperoleh, selanjutnya dilaporkan sebagai pola hubungan tertentu (Sugiono, 2005). 


\section{PEMBAHASAN}

\section{Kebersamaan dalam Momen-momen Sosial Keagamaan}

Praktik keagamaan yang ada di masyarakat pedesaan khuusnya di Desa Guwa Lor menjadi sebuah momentum kebersamaan, mereka tidak lagi diwarnai oleh perbedaan aliran atau paham yang mereka yakini. Ketika hal itu diadakan acara keagamaan masyarakat secara spontanitas guyub membaur menghadiri acara tersebut.

Kondisi masyarakat kecamatan Kaliwedi mayoritas $80 \%$ berprofesi sebagai petani, $10 \%$ sebagai buruh atau karyawan dan $10 \%$ sebagai pedagang; mengalami lonjakan penduduk sebesar 0,3\% sejak tahun 2018 sampai tahun 2019 menjadi 3.023 orang; 1486 pria; 1537 wanita sehingga kepadatan penduduknya mencapai 56 jiwa $/ \mathrm{km}^{2}$ (Badan Pusat Statistik, 2016). Mayoritas agama yang dianut masyarakat adalah Islam dengan jumlah 3.023 orang dengan tempat ibadah memiliki 2 buah masjid, 86 mushollah.

Acara keagamaan sekalipun dalam keyakinan yang sama yaitu Islam, Kegiatan yang ada di masyarakat Guwa Lor tersebut memiliki ciri khas masing-masing. Sebagai contoh yang dilihat dalam observasi di lapangan adalah bacaan tahlil, talqin, istigosah, dan lainnya. Namun perbedaan tersebut tidak lagi dipersoalkan karena dalam pandangan masyarakat, inti yang paling pentung dalam kagiatan keagamaan ini adalah hadirnya hati dalam berdzikir.

Halinisejalandenganfungsiagama yaitu sebagai seperangkat pengetahuan, kepercayaan, moral, dan norma aturan lainnya yang disepakati sebagai sumber tatanan hidup di masyarakat sehingga menumbuhkan ketentraman setiap masyarakat dan membuat mereka lebih beradab (Ali, 2007).
Kecenderungan pada dinamika ritual tersebut mampu memberikan ruang komunikasi dengan sesama warga masyarakat, sehingga hal tersebut mampu mempererat tali persaudaraan baik karena sebab adanya tali pernikahan atau karena sebab kerabat tetangga, namun yang jelas hal itu tampak jelas dipengaruhi oleh insting keagamaan di mana agama memiliki fungsi ambivalen yang sangat bertolak belakang yaitu sebagai social cement atau conflict interest (Zakiyuddin, 2002).

Ritual keagamaan juga faktor perekat hubungan individu atau kelompok dengan latar belakang yang berbeda sebagai alat untuk membangun solidaritas dan loyalitas yang tinggi bagi para pemeluknya dan sebagai salah satu faktor yang dapat memunculkan konflik sosial dengan melibatkan sisi lain dalam emosi manusia (Jamil, 2007). Mengelolah kemajemukan agama dan kepercayan yang sarat dengan berbagai kepentingan yang sering bersebrangan sehingga pluralitas dan kemajemukan rentan menjadi sumber konflik atau perselisihan (Juergensmeyer, 2008).

Agama dan kepercayaan adalah kebutuhan dasar bagi setiap orang sudah dijamin kebebsannya dalam UUD tahun 1945 pasal 28E ayat 1 . Semua warga Negara mempunyai hak untuk memeluk agamnya masing-masing termasuk memilih pendidikan, pekerjaan, kewarganegaraan dan tempat tinggalnya. dan dipertegas pada pasal 28E ayat 2, pilihan tersebut atas sikap, fikiran dan keyakinan masingmasing tanpa ada paksaan dari siapa pun (Situmorang, 2019).

Pendekatan sejarah lokal yang dilengkapi pemahaman kebudayaan yang memperlakukan realitas sebagai teks sosial, menjadi warisan sosiologis yang mendesak untuk digunakan kembali. Manfaatnya, diluar untuk menghindari generalisasi yang serampangan, juga 
untuk memberikan kejelasan empiris: bagaimana sebenarnya setiap komunitas masyarakat memperlihatkan jejak sejarahnya sendiri dalam membangun toleransi.

Pada beberapa kasus kegiatan ritual keagamaan seperti tahlilan dan acara nujuh bulan, memilik ciri khas masing-masing tergantung gaya ritual dari tokoh agama yang memimpin acara tersebut. Walaupun memiliki tata cara yang berbeda dalam pelaksanaanya, sebagaimana pandangan dari Peter L. Berhge yang mengatakan bahwa konsensus dan konflik selalu melekat bersama-sama di dalam setiap kehidupan sosial (Dhohiri, 2003, hal. 15).

Kegiatan ritual tahlilan misalnya masyarakat ada yang setujuh dan ada yang tidak setujuh, hal ini tidak menjadi dasar dalam pelaksanaanya, namun yang terjadi dalam praktiknya acara tahlilan tersebut masih dilakukan oleh kerabatnya sendiri bahkan yang menolak pada akhirnya ikut membaur dalam acara tersebut sehingga walaupun berbeda paham mereka tetap hadir dalam acara tersebut sebagai bentuk penghormatan pada kerabatnya.

Faktor kekerabatan tersebutmenjadi sebab adanya orientasi pemahaman integrasi antar elemen sosial sehingga memiliki perasaan di dalam kelompok terhadap kelompoknya atau kelompok lain di luar kelompoknya tetap memiliki sikap toleran (M. Setiadi \& Kolip, 2013). Makna kehadiran pada acara tahlilan sendiri tidak selalu sama dari setiap orang yang hadir, sehingga masyarakat yang heterogen dalam pemahaman ini mampu memahami esensi atau maksud yang dibangun oleh tokoh agama bahwa biarpun berbeda namun acara tersebut memiliki tujuan yang sama yaitu berdo'a dan mendo'akan. Resiprositas ini merupakan basis relasi yang ada di masyarakat dan tiap orang berorientasi pada orang yang lain (Perdue, 1986).
Acara pernikahan juga mampu memberikan warna harmonis bagi setiap orang yang hadir, dengan latar belakang yang berbeda mereka sanggup menjaga sikap toleran dalam ritual sakral tersebut, hal ini karena inti dari acara pernikahan adalah menjalin kekeluargaan dan ketentuannya sama walaupun dalam urutannya seringkali berbeda, Proses ini dianggap tidak mendasar karena telah dipenuhinya syarat rukun nikah.

Tujuan utama dalam ritual pernikahan adalah menyegarkan struktur sosial, dengan menyatunya dua keluarga besar yang terkadang berbeda paham aliran agama mereka tumbuh menjadi keluarga baru yang memiliki kesamaan tujuan. Dari sikapnya yang menunjukan pembaruan akibat kekerabatan baru, menuntut adanya sebuah ketaatan baru ketika terjadi krisis atau adanya pertentangan akibat masalah akulturasi paham keagamaan. Perbedaan ini membuat pengetahuan baru untuk keduah belah pihak sehingga hubungan dua keluarga itu menjadi cair dan menyebabkan perubahan sosial akibat dari situasi baru yang berbeda dengan situasi sebelumnya (wawancara dengan Umar, 16 April 2020).

Sikap masyarakat menyikapi ragam perbedaan dalam tata cara ritual tersebut tidak menimbulkan konflik, namun justru sebaliknya membuat akulturasi antara agama dan budaya yang semakin beragam, menjadi penguat tradisi baik bagi agama dan masyarakat serta menyatukan perbedaan dalam satu kegiatan. Tokoh agama juga tidak mempersoalkan seremonial dalam pelaksanaan kegiatan tersebut dan mendukungnya dalam batas-batas yang tidak berlebihan dalam beragama.

Stereotip yang terpelihara oleh opini masyarakat tersebut khususnya yang berkaitan dengan kerukunan umat agama, masyarakat sejatinya telah 
mampu mengelola adat istiadatnya dalam upaya menjaga tolerasi walaupun memiliki perbedaan dalam cara beragama dan ritual keagamaannya, kelompok sosial masyarakat yang berbeda tersebut mampu saling menjaga toleransi keberagamaanya, mereka selalu mendapat tempat terhormat pada setiap kesempatan yang ditawarkan sehingga masyarakat mampu berintraksi sosial dengan saling menghargai perbedaan atas paham keagamaannya. Masyarakat lebih toleran, inklusif dan humanais.

Harmoni beragama di masyarakat pedesaan juga menyebabkan sikap toleransi mengalami sandungansandungan kecil khususnya disebabkan oleh perbedaan persepsi tentang cara menghampiri teks agama dari sisi teologis atau rana tekstual akan menimbulkan masalah lain ketika naskah tekstualteologis dimaknai melalui pendekatan sosio-historis disebabkan akan memunculkan makna atau interpretasi yang berbeda, dan hal tersebut tidak bisa dihindari jika antara komunitas dengan komunitas lainnya berbeda dalam memahami sesuai dengan kebenarannya sehingga diperlukan pemahaman akan substansi untuk menghadapi problem kemanusiaan, bukan hanya sebatas toleransi tetapi ada hubungan yang dinamis (Kuntowijoyo, 1993).

Praktik keagamaan lain yang menyebabkan adanya harmoni beragama di Desa Guwa Lor secara umum adalah tradisi mapag sri, sedekah bumi, istighosah, selametan, takliman dan muludan. Oleh semua tokoh (sepuh) agama sepakat bahwa tradisi ini sudah ada jauh sebelum Islam datang namun tetap dilaksanakan dan harmoni masyarakat tetap terjaga dan semakin erat karena menimbulkan empati kebersamaan, saling bahu membahu tanpa pandang paham agamanya.
Melalui pendekatan persuasif yang dilakukan oleh tokoh agama, mereka menekankan pentingnya pemahaman agama yang benar dan kerugian akibat adanya intoleransi umat, memberikan kunci pemahaman untuk menjalankan agama dalam akulturasi adat istiadat yang baik sehingga tidak bertentangan dengan agaa dan bisa dilaksanakan dengan baik dengan sikap toleran.

Menurut Umar, salah satu upaya yang dilakukan untuk pembinaan kerukunan umat beragama adalah melalui kegiatan keagamaan yang diinterpretasikan dalam kegiatan ritual keagamaan, salah satu kegiatan ritual yang digunakan untuk mempererat tali persaudaraan kegiatan ritual keagamaan sedekah bumi. Kegiatan ini dapat mengurangi gesekan yang terjadi dalam beragama karena menghadirkan semua warga desa dalam jumlah besar berkumpul memeriahkan acara syukuran atas karuniah Tuhan dan mereka saling mendoakan keselamatan masa tanam sampai masa panen sehingga diperoleh hasil yang maksimal (wawancara dengan Umar, 21 April 2020).

Upaya lain adalah melalui jamiyahjamiyah seperti jamiyah yasin di mana juga dihadiri oleh berbagai lapisan masyarakat dan disediakan ruang dialog untuk saling memahami antaraliran paham agama, tentang aturan yang ada dalam agama, saling menghargai melalui dialog dan berbagi informasi, ide dan gagasan terhadap isu-isu aktual kaitannya dengan masalah sosial-kemanusiaan, untuk mendapatkan solusi atas masalah yang sedang dihadapi melalui ruang dialog dan majelis jamiyah (Ridho, 2019).

Kegiatan masyarakat dalam jamiyah tersebutmenjadiajang untukbersosialisasi tentang gagasan-gagasan baru, sosialisasi dan peningkatan pemahaman agama di masyarakat. Kegiatan tersebut dapat dipahami sebagai upaya paling efektif 
dalam menjalin komunikasi, untuk saling mengenal dengan komunitas umat beragama, menghilangkan sekat kekakuan yang sering menjadi pemicu gesekan atas prasangka yang sebenarnya tidak diperlukan karena dapat diselesaikan melalui dialog budaya, keterbukaan terhadap keyakinan orang lain, memberikan ruang untuk sikap saling percaya dan menjaga solidaritas antarsesama. Upaya yang dikelolah dalam jaminan saling percaya antarkomunitas memberikan jedah ruang terjadinya konflik yang lebih luas.

Upaya tersebut menjadi usaha yang sangat fektif dalam menjalin rekonsiliasi ketika ada masalah, memupuk rasa saling percaya antar komunitas agama dan menyambung relasi yang kurang baik menjadi lebih erat dan terbuka. Konflik-konflik yang mencuat menjadi terkendali dan dapat dicegah dengan adanya ruang dialog dan hubungan yang baik yang terus dibangun dan dipelihara oleh masyarakat melalui konsesus yang diwakili oleh tokoh agama.

Masyarakat paham betul akan kerugian adanya konflik sehingga mereka segera merespon bila ada gesekan yang akan memicu intoleransi. Melalui gambaran atas semua realitas konflik atau kekerasan dari komunitas agama di tempat lain yang sangat merugikan, bahwa gerakan tersebut menjadi pelajaran bersama supaya tidak terjadi atau terulang di desa Guwa Lor.

Gagasan yang dibangun didasarkan pada semangat perdamaian dan anti kekerasan melalui komunikasi internal secara emansipatoris sehingga komunikasi antarsesama lebih didasarkan pada prinsip kesetaraan, terbuka, bebas dan pengakuan pada dogma apa yang dikatakan sebagai yang paling benar dapat dikesampingkan dan tidak berprasangka atau penilaian sepihak atas stereotip yang merugikan diri sendiri.
Tujuanuntukmencapaihidupdamai terbangun sejak lama, secara bersamasama mereka paham betul apa yang harus diaplikasikan dalam komitmen bersama masyarakat. Komunitas agama saling duduk bersama dalam menyelesaikan setiap masalah sosial kemanusiaan atas dasar keinginan hidup sebagai tetangga yang baik. Faktor pendukung harmoni beragama di Guwa Lor adalah adanya sikap saling menghormati terhadap praktik keagamaan orang lain, dengan memahami dan menghargai perbedaan, sebagai entitas pendukung kerukunan, saling mensuport ini dapat mendorong terjadinya harmoni beragama.

Masyarakat sangan menghindari sikap egoisme, menyalahkan praktik keagamaan orang lain, klaim diri merasa alirannya paling benar dengan menyerang paham orang lain, eksklusif dan tidak mau memahami kebebsan keyakinan dalam beragama aliran lain dapat menghambat terciptanya kerukunan dalam harmoni masyarakat.

Kelompok dan aliran dalam Islam di Desa Guwa Lor sangat beragam namun tidak menjadikannya sebagai sesuatu yang dapat menggangu bagi terciptanya kerukunan. Karena mereka sudah memahami dan mampu mencegah dan menangani konflik secara dini melalui dialog sehingga melahirkan sikap keberagamaan terbuka, inklusif dan bebas dalam menjalankannya. Praktik keagamaan yang menonjol diantaranya muludan, safaran, nujuh bulan, tahlilan 7, 40, 100, dan 1000 hari setelah kematian, ngunduh mantu, dan lain sebagainya.

Nasirudin, mengatakan bahwa terciptanya harmoni beragama dalam praktik keagamaan yang harmoni dalam perbedaan di desanya berawal dari sikap keterbukaan dan mau belajar kepada orang lain dan bersosialisasi, komunikasi atau berbaur dengan umat beragama yang berbeda aliran mulai 
lingkup keluarga dan masyarakat (wawancara dengan Nasirudin, 20 April 2020). Adanya forum dialog bisa menjadi alternative yang mengambat terjadinya konflik dan salah satu alternative untuk menyelesaikan masalah tersebut secara bersama (Sumbulah, 2015).

Menurut Rosyidi, kerukunan yang terbentuk dipengaruhi oleh kemauan umat beragama yang berbeda paham ataupun aliran untuk membuka diri dan berdialog atau bersosialisasi, adanya kesadaran untuk saling menolong dalam rangka mewujudkan kerukunan dan adanya kepatuhan terhadap pemerintahan di mana pemerintah desa juga ikut melindungi dan bersikap netral terhadap realitas prular masyarakat (wawancara dengan Rosyidi, 20 April 2020).

Pembinaan kerukunan kerap dilakukan dengan keteladanan dari aparat desa dan tokoh agama dengan menghilangkan sikap ego dan keengganan masyarakat untuk menghormati, memahami, perbedaan kepada orang lain akan prinsip-prinsip religiusitas dari alirannya masing-masing. Pergeseran sikap masyarakat dari eksklusif ke inklusif merupakan bentuk perubahan transformasi sosial dalam teologis yaitu fundamentalisme, konservatisme, dan ekumenisme (Knitter, 1985).

Menurut Mahfudz, kebersamaan dalam bingkai kemajemukan merupakan sikap yang dapat diwujudkan ke dalam sikap kerukunan, sebaliknya fanatisme berlebihan dapat menghancurkan ruang harmoni yang telah terbangun. Satori, berpendapat bahwa kerukunan yang terbangun di masayarakat merupakan sikap yang tumbuh secara alamia dari pembiasaan masyarakat dalam berinterkasi misalnya melalui kegiatan tahlilan karena dalam pelaksanaanya mengundang semua lapisan masyarakat dan dihadiri oleh semua warga (wawancara dengan Mahfudz, 20 April 2020).

Tahlilan, syukuran dan slametan atau kegiatan lainnya merupakan ragam dari praktik keagamaan masyarakat yang melibatkan semua unsur masyarakat dalam ragam budaya sehingga mampu memperkuat harmoni beragama dan mampu menumbuhkan rasa kekeluargaan, kebersamaan tidak lagi ada sekat agama. Geertz menyimpulkan bahwa Islam di Jawa merupakan akulturasi animisme dan hinduisme, sehingga memberikan corak tersendiri bagi Islam Jawa (Geertz, 1983).

Praktik keagamaan yang berbeda seperti tahlilan dalam rangka selametan atau syukuran menjadi media interaktif berbagai kelompok agama mengelolah kebersamaan dan masih populer sampai sekarang seperti temuan dari Beatty (Beatty, 2003), Woodward (Woodward, 1988), dan Hefner (Hefner, 2000). Mereka mengeksplorasi keterkaitan antara agama dan budaya yang menjadi faktor dominan terjadinya kemajemukan sosial di masyarakat.

Tradisi selametan sekalipun disikapi beragam oleh aliran lainnya namun untuk menjaga dan menghormati tetangga, mereka mampu menjadikan perbedaan tersebut sebagai harmoni dalam beragama dengan ikut hadir dalam acara tersebut sehingga masyarakat yang memiliki ragam ritual dan budaya bisa disatukan disebabkan dalam ritual keagamaan yang ada tidak lagi ada sekat di antara penganut aliran paham agama dan mazhab yang berbeda-beda.

Sikap inklusif di masyarakat dapat menciptakan terjadinya ruang harmoni dalam kehidupan warga, bahkan menyulut konflik atau kekerasan atas nama agama dapat dicegah sedini mungkin. Sikap ini juga muncul karena adanya kekaguman atas tokoh agama di 
desa Guwa Lor yang mampu memberikan sikap toleran, adil dan merangkul semua perbedaan.

Menurut teori psikologi terjadinya konflik atau kekerasan yang menggunakan nama agama terjadi akibat adanya masyarakat yang tersinggung oleh perasaan narsistiknya, yaitu perasaan panatisme berlebih disebabkan oleh penilaian subjektif yang dangkal terhadap kelebihan atau keunggulan kelompoknya (Fromm, 2004). Sehingga disinilah peran utama tokoh agama yang dapat memainkan ego dari masyarakat untuk memicu pergolakan kepentingan yang harus diwaspadai.

Beuken berpendapat bahwa kekerasan atas nama agama ditimbulkan oleh pembacaan teks agama yang dijadikan sebagai bahan untuk melegitimasi tindakannya menjadi pembenaran atas perilaku kekerasan yang dijadikan sebagai ideologi dan agama menjadi faktor penguat budaya identitas yang dijadikan tameng untuk pembenaran tindakannya (Beuken \& Kuschel, 2003).

Kasus kekerasan atas nama agama menjadi bukti bahwa agama sering dijadikan sebagai akar pembenaran atas terjadinya konflik agama. Simbol identitas keagamaan menjadi representasi masyarakat yang kuat dalam membenarkan tindakan komunalnya (Azra, 1999). Simbol identitas komunalisme agama menjadi pemandangan yang dianggap biasa dalam membangun relasi beragama. Semangat identitas komunalisme ini telah mengakar kuat di masyarakat sangat rentan memicu kekerasan yang berlindung dibalik agama.

Edukasi tokoh agama tentang pluralisme sangat beragam dianataranya mengajarkan tentang keragaman sebagai kenyataan sosial yang fitrah, sikap menghargai, selalu terbuka terhadap keyakinan paham agama orang lain, dan menekankan kesetaraan identitas makhluk di hadapan sang pencipta. Keragaman pada sikap atau pandangan tersebut memberikan penilaian akan sikap tokoh agama sebagai moderat atau konservatif.

Makna harmoni beragama, dimaknainya sebagai penghargaan atas keyakinan, paham atau aliran orang lain yang bersifat ko-eksistensi, atau progressif dan pro-eksistensi. Harmoni beragama yang dilakukan secara internal di masyarakat terhadap komunitas melalui sosialisasi atau penguatan berbasis komunitas dan dalam lingkup eksternal melalui kerja sama khusunya masalah diluar ibadah atau keyakinan seperti masalah kemanusiaan dan hubungan dengan sesamanya.

\section{Peran Kepemimpinan Agama dalam Membangun Kesadaran dan Praktik Toleransi}

Weber berpendapat bahwa peran pemimpin bisa melakukan inisiasi perubahan ke arah radikal atau dinamis (Ritzer, 2004). Weber melihat adanya suatu perubahan akibat adanya interaksi sosial di masyarakat, faktor eksternal yang mendorong terjadinya tindakan masyarakat untuk melakukan suatu perubahan dan adanya intruksi dari orang yang dipercaya dan disegani sehingga menimbulkan dan melahirkan adanya perubahan yang inovatif, dinamis atau radikal. Weber mengklasifikasikan konsep tersebut kedalam tiga tipe pola kepemimpinan yaitu karismatik, tradisonal dan legal rasional (Scharf, 1995).

Kaitannya dengan pengaruh tokoh agama di pedesaan sangat dominan menghegemoni seluruh unsur kehidupan masyarakat mulai dari soal pernikahan, nujuh bulan, kelahiran anak, khitanan, kematian, selamatan, dan kegiatan sosial lainnya. Semua ritual kegiatan masyarakat selalu melibatkan tokoh agama khususnya berkaitan 
dengan do'a-do'a yang selalu dilantunkan dalam seremonial pada acara tersebut. Dalam tataran ritual tersebut masyarakat menanggalkan identitas aliran paham keagamaannya.

Weber, memandang tipe tokoh agama tersebut memiliki perbedaan pada sifat atau karakternya di mana tipe tradisonal dan rasional memiliki relasi yang stabil dan kontinu sedangkan tipe karisma murni tidak berlangsung lama namun tipe kepemimpinan ini dapat diwariskan kepada orang lain disebabkan oleh kedudukan terhormatnya di masyarakat sebagai buah dari keteladanan sikap tokoh agama. Karisma ini oleh weber dikatakan sebagai buah dari pengabdian atas jasa seseorang yang telah dilakukan pada masyarakatnya.

Weber mengkategorisasikannya menjadi dua yaitu dominasi kepentingan dan dominasi kekuasaan untuk memerintah sehingga yang diperintah waib tunduk atau patuh (Wrong, 2003). Menurut Weber, munculnya otoritas anggotanya karena faktor warisan atau. Konsepsi pada hal-hal sifat pribadi adalah bentuk transformasi yang berubah menjadi konsepsi dan bisa disalurkan melalui bentuk kekuatan immaterial supranatural (Scharf, 2004).

Menurutnya, siapun punya kesempatan untuk mengkompromikan setiap struktur dalam masyarakatnya sendiri. Setiap orang dapat memberikan ide-ide perubahan atas dasar tujuan atau maksudnya. Melalui paradigma ini, manusia dapat dipandang sebagai symbol interaksional dan pribadi yang khas sehingga mempunyai watak dualisme. Tekanan dari luar tidak dapat membentuk sikap dasar manusia, karena ada faktor yang lebih dominan memengaruhi diri manusia sehingga tidak bisa dengan mudah tunduk pada tekanan dari luar.

Peran tokoh agama mengedukasi masyarakat juga terlihat cenderung terbatas plafonnya dalam arena sosial keagamaan dan sangat sulit memasuki anak tangga berikutnya. Transformasi sosial tokoh agama dalam mengawal interaksi sosial masyarakat pada tingkatan sosial masyarakat bawah yang hampir tak terbatas mampu memasuki wilayah dunia selain sosial keagamaan yang lebih luas dan modern, memberikan kecenderungan untuk bebas dari budaya inferior yang merupakan konsekuensi logis atas terlalu lamanya dikungkung oleh keterbelakangan struktural (Umam \& Ghazali, 2019).

Kompleksitas fenomena keberagamaan di desa cenderung tidak memunculkan konflik atau ketegangan berlatarbelakang kultural atau etnik disebabkan oleh kuatnya interaksi atau hubungan sosial kekeluargaan di masyarakat (Imarah, 1999) fanatisme pada tokoh agama juga menjadi faktor terbentuknya kerukunan yang ada di masyarakat (Nugroho, 2016).

Elemen-elemen sosial masyarakat khususnya tokoh agama sebagai kelompok otoritas yang mampu memadukan sakralitas dan transenden, fenomena sosial budaya serta profan karena kedudukannya sebagai orang yang paham agama dan sekaligus sebagai kaum cendekia, ikut memainkan peran yang cukup signifikan dalam melakukan adaptasi terhadap masyarakat dan menjadi figur dominan yang mampu memberikan kotribusi sebagai penengah dalam setiap masalah yang terjadi (Ridho, 2018).

Masyarakatnya menganggap pada setiap kegiatan bukanlah sekadar sebagai kewajiban bagi penganutnya saja, tetapi lebih dari dari itu, masyarakat pada umumnya menganggap bahwa tokoh masyarakat merupakan orang yang mempunyai dan layak mengemban pertanggugjawaban sosial bersama dalam menjaga kerukunan antarumat beragama. 
Bentuk tanggung jawab tersebut dengan ikut serta memberikan pemahaman pada anak-anaknya melalui pendidikan agama di masjid, madrasah dan mushallah, karakter wibawah timbul dari peran tokoh agama yang memberikan teladan tutur kata maupun tingkah lakunya. Proses pendidikan agama tersebut mengajarkan adanya pluralitas sehingga anak-anaknya mampu memahami gambaran-gambaran umum tentang agama yang berbeda dan membentuk sikap toleransi dan inklusivitas sejak dini (Rohman, 2016). Tidak mengherankan jika kemudian peserta didik merasa segan dan hormat pada tokoh agama hal tersebut berpengaruh pada terciptanya masyarakat yang harmonis .

Keberadaannya tokoh masyarakat yang hadir dalam setiap acara yang diadakan warga juga memunculkan penghormatan tersendiri dari masyarakat yang berada dalam lingkaran sejarah yang panjang, tokoh agama memiliki kemampuan sosial untuk mencegah daan mengelolah konflik atas nama agama dengan aktif forum lintas agama dan forum umat beragama dalam mengembangkan keberagamaan masyarakat (Arwani, 2014).

Selain itu, tokoh agama mengadakan dialog intensif dengan jemaah. Tradisi lain di masyarakat adalah gotong royong, kerja bakti saling membantu ketika ada kematian, kelahiran, mengelolah lahan, panenan, muludan, safaran dan lain sebagainya. Semua bentuk kegiatan tersebut dilandasi oleh asas yang bersumber dari agama sehingga dalam pelaksanaanya mengundang seluruh warga desa tanpa kecuali dari mulai anak-anak sampai orang tua ikut terlibat dalam kemeriahan acara tersebut.

Tokoh Agama membangun harmoni beragama dengan melakukan kegiatan sosial untuk menumbuhkan rasa persaudaran yang alami, seperti jamiyah, sarasehan, dan paguyuban. Kiai, tokoh agama dan pejabat desa memberikan kesempatan yang sama untuk setiap aliran paham agama dalam melakukan kegiatan yang sifatnya non-ibadah dengan cara bersama-sama. Model kehidupan seharihari di desa sudah tumbuh alamiah untuk saling menghormati adalah cara yang dilakukan masyarakat untuk menghargai alam dalam mewujudkan kerukunan umat beragama.

Kerukunan umat beragama juga masih diwarnai oleh sikap negatif dari beberapa warga yang masih memiliki fanatisme sempit, egoism terhadap keragaman adat atau budaya yang ada, mereka merasa benar sendiri dan gagal paham terhadap keyakinan orang lain serta sikap tidak terbuka terhadap cara beragama orang lain menjadi sumbu api konflik namun berkat keuletan dari para tokoh agama yang mencontohkan sikap keteladanan yang positif mampu memberikan kesadaran pada masyarakat akan pentingnya menjaga kerukunan hidup beragama, keragaman budaya melalui intensifikasi dialogis dengan masyarakat bagi kerukunan masyarakat yang mempunyai keragaman paham, aliran dan mazhab.

Masyarakat pedesaan Guwa Lor menjalankan kehidupan beragama berdasarkan keterbukaan, pluralitas pemahaman agamaIslam, berbeda dengan gaya yang dianut oleh masyarakat lain yang mengindoktrinasi tradisi atau adat istiadat atau aliran tertentu. Komunitas pedesaan tidak hanya mengajarkan satu tradisi atau kebiasaan; diajarkan agar orang tidak berpegang pada tradisi atau adat secara fanatik dan ekstrem.

Lebih lanjut Ahmad Said menjelaskan, tidak diajarkan kepada masyarakat masyarakat desa Guwa Lor bahwa pendapat si A atau si B yang paling benar, kemungkinan kesalahan 
selalu ada. Pemikiran dan pendapat dari berbagai tokoh kita diskusikan, dan dilakukan analisis terhadap semua pendapat, minimal tarjih, kemudian disampaikan kepada masyarakat dengan tujuan mengetahui dan memahami dengan baik alasan setiap pendapat itu" (wawancara dengan Ahmad Said, 21 April 2020).

Pemimpin agama sering kali terbuka dan berkomunikasi dengan komunitas, ketika mereka mendengar atau menghadapi pertanyaan yang tidak mereka pahami atau pegang. Menariknya, dalam studi apapun, masyarakat menerima bahwa tidak ada metode atau tindakan yang sepenuhnya akurat dibandingkan dengan praktik atau kebiasaan lain. Dalam kasus ushuliyyah misalnya, para pemuka agama menekankan pada prinsip-prinsip Islam yang tidak boleh dilanggar tetapi dalam kasus furu'iyyah, orang-orang bebas melakukan ijtihad setelah memahami alasan dan menguasai ilmu alatnya. Oleh karena itu, dalam struktur sosial masyarakat pedesaan, para pemuka agama tidak dapat memaksakan fakta kepada masyarakat sebagai harga tetap yang tidak dapat diganggu gugat sama sekali.

Sedikit berbeda dengan budaya pedesaan Guwa Lor, dalam hal ini relasi sosial, di mana masyarakat meneliti semua praktik atau adat istiadat dengan pendekatan dan definisi yang berbeda tetapi praktik atau adat itulah yang sebenarnya ditekankan. Yang terpenting jangan menyalahkan pandangan yang berbeda, mereka tidak terbatas pada mempelajari tradisi atau adat istiadat yang berbeda, tetapi memilih tradisi atau adat nahdliyin dalam praktiknya, misalnya, karena ini adalah kegiatan sosial utama masyarakat pedesaan (wawancara dengan Satori, 21 April 2020).

Dengan terus mengkaji amalan atau adat istiadat lain, Satori menekankan pentingnya suatu tradisi atau perilaku yang dianut dan tidak menutup kemungkinan mengambil pandangan yang paling kuat. Ini dirancang untuk mencegah orang depresi dan tersesat dalam hidup mereka. Interaksi sosial kelompok Guwa Lor, mengamati baik praktik maupun kebiasaan dengan metode dan gaya yang berbeda. Namun ditegaskan bahwa yang dijaga dan dilestarikan di Guwa Lor adalah praktik atau adat istiadat nahdliyin dan yang terpenting tidak menyalahkan pandangan yang berbeda (wawancara dengan Satori, 21 April 2020).

Mengalami tradisi kehidupan beragama ini, Bunyamin, salah satu tokoh masyarakat di Desa Guwa Lor, mengakui bahwa nilai-nilai kemajemukan berkembang di masyarakat pedesaan meski tidak serta merta menganut konsep pluralisme ala Barat. Ia mengungkapkan bahwa ideologi dan tatanan kehidupan beragama di masyarakat pedesaannya sangat mendorong toleransi umat (wawancara dengan Bunyamin, 21 April 2020).

Masyarakat pedesaan Guwa Lor, jauh dari eksklusif dan ekstrem, menjalankan sistem sosial yang responsif dan adaptif dengan pluralitas penduduk Guwa Lor. Landasan kemajemukan Kiai Bahrudin adalah gambaran seorang ulama yang membangun pemikiran keislamannya atas dasar pengalaman sosialnya yang panjang, membaca dan terlibat dengan berbagai pemikiran Islam, sehingga pada akhirnya menempatkan dirinya pada jalan yang moderat. Kekuatan perdamaian yang ia bangun dalam komunitas pedesaan Guwa Lor merupakan cerminan perjuangannya di bidang sosial dan misinya menyebarkan Islam kaffah moderat.

Kiai Bahrudin menyerap banyak pemahaman yang berbeda dari berbagai literatur arus utama dalam perjalanan filosofisnya, seperti yang digunakan oleh ulama ahlus sunnah lainnya. Ia juga secara 
kritis mengadopsi cara berpikir yang berbeda dari pesantren dan organisasi Nahdlatul Ulama Wahid Hasyim. Oleh karena itu, Kiai Bahrudin tidak mengembangkan teori fiqhnya atas dasar fiqh tradisional atau adat." (wawancara dengan Gozali, 21 April 2020).

Ajaran agama yang lebih didominasi warna nahdliyin merupakan salah satu faktor yang menyebabkan masyarakat di luar memandang masyarakat pedesaan Guwa Lor tidak ekstrem dan eksklusif. Hal ini didasarkan pada latar belakang, selain adanya tokoh agama yang hampir seluruhnya merupakan tokoh NU atau berafiliasi dengan lembaga kemasyarakatan NU, juga adanya kecenderungan menerima pemahaman agama sebagai model ideal bagi masyarakat pedesaan di Guwa Lor.

Relativisme dalam konteks masyarakat pedesaan sebagaimana tercermin dalam konsep di atas sangat dibutuhkan untuk meredam eskalasi konflik internal umat Islam. Perbedaan pemahaman suatu teks (nash) dapat menimbulkan kontroversi dan perselisihan di kalangan umat Islam, seringkali mengakibatkan tindakan kafir (takfir) yang cenderung lebih emosional daripada ideologis. Ketidaktahuan itu merupakan justifikasi terpenting untuk melegalkan berbagai tindak kekerasan dan anarkisme atas nama agama.

Menurut Satori, masyarakat Guwa Lor telah memahami prinsip bahwa kebenaran tetap kebenaran. Ketika seseorang sudah yakin akan kebenarannya, maka ia harus berpegang pada kebenaran itu. Masalahnya ketika ada kontradiksi kebenaran yang dipertahankan oleh masing-masing penganutnya, takfir menjadi "pelarian ideologis " untuk keluar dari krisis epistemologis. Masyarakat pedesaan meyakinibahwa kuncikeluar dari masalah ini adalah dengan mengedepankan akhlak, selain menjunjung tinggi prinsip keimanan." (wawancara dengan Satori, 21 April 2020).

Dari rangkuman temuan penelitian di atas, dapat dipahami bahwa masyarakat pedesaan di Guwa Lor mengenal dan mentransinternalisasikan prinsip-prinsip pluralisme dalam iklimnya, meskipun dalam definisi varian barat kosa kata pluralisme belum diadopsi sepenuhnya. Memperdalam ilmu agama dan menerapkan akhlakul karimah dalam kehidupan beragama dan bermasyarakat, merupakan substansi sekaligus alat untuk mewujudkan pentingnya toleransi dalam masyarakat pedesaan Guwa Lor.

Pentingnya toleransi dalam masyarakat sejak itu ditanamkan di Guwa Lor oleh para pemuka agama dan masyarakat; sikap atau pendapat pluralis, dan toleransi terhadap perbedaan agama; Para pemimpin komunitas menerima, sejatinya semua manusia harus menganut satu agama saja, sehingga semua jenis akidah dan agama yang tidak dianggap sebagai agama Tuhan adalah palsu, tidak setia, dan harus disingkirkan dari muka bumi, karena itu bertentangan dengan hakikat hidup manusia dan keadilan Tuhan. Ini.

Keterlibatannya dengan kehadiran hukum agama dalam masyarakat di Guwa Lor membangkitkan kesadaran bahwa bagi praktik umum pengikutnya, setiap agama memiliki doktrin dan kerangka hukumnya sendiri. Penduduk pedesaan di Guwa Lor juga enggan menolak filosofi agama dan sistem hukum seperti itu. Semua sistem hukum yang tidak didasarkan pada wahyu adalah salah, tidak adil dan tidak beriman sehingga sistem hukum dan kepercayaan agama lain pada akhirnya harus diperluas kepada pemeluk agama masing-masing; selama itu tidak mengganggu keistimewaan atau bahkan merusak keyakinan pemeluk paham keagamaan lain. 
Berkaca pada pandangan Satori sebelumnya, pada praktiknya setiap agama bertujuan untuk menciptakan kebaikan dan kekayaan bagi pengikutnya, yang pada umumnya mengarah pada perwujudan prinsipprinsip moral universal dalam kehidupan bermasyarakat, terlepas dari hambatan primordialisme saat ini. Dengan demikian, yang perlu ditanamkan pada setiap umat Islam, terutama generasi muda Islam, adalah kemauan untuk bekerjasama dan terlibat dengan pemeluk agama lain dalam mencapai perdamaian dan kebaikan bersama, sebagai aplikasi seruan Islam untuk bersatu.

Kenyataannya, masyarakat pedesaan di Guwa Lor, yang bereaksi terhadap disparitas dan ketimpangan pemahaman hukum agama, lebih mengedepankan keterbukaan dan jauh dari kata kaku. Menurut mereka, ajaran Islam juga mengandung tafsir yang berbeda (pluralitas). Dari sudut pandang adat istiadat, praktik atau perilaku, gaya dan penafsir, tafsir Islam sangat berbeda. Ada beberapa praktik atau hasil fiqh yang terbukti di bidang fiqh. Misalnya, dalam teologi (ilmu Kalam) muncul mazhab / aliran yang berbeda yang mengungkapkan pendapat yang seringkali saling bertentangan. Artinya ada pluralitas paham dalam Islam itu sendiri yang tidak bisa disatukan.

Tidak setiap praktik atau kebiasaan, sekte atau bahkan orang harus mengklaim sebagai kategori yang paling benar yang diberikan dalam teks wahyu Tuhan untuk memahami ajaran Islam. Dalam mengakui pandangan agamanya, komunitas atau individu harus menerima bahwa kebenaran dan kesalahan akan ada dalam segala hal. Misalnya, terhadap partai lain, partai Nahdliyin bukan yang paling kanan, begitu pula sebaliknya. Budaya religi NU tidak lebih istimewa dari Muhammadiyah atau lainnya. Masyarakat dan tokoh agama mengungkapkan bahwa yang dibutuhkan adalah pemahaman dan dialog yang terbuka di antara semua kelompok.

Menanggapi nuansa dan variasi adanya furu'iyyah yang merupakan konsep yang masih memiliki perbedaan dalam definisi, telah berkembang dan diterima dengan baik oleh masyarakat, misalnya berkenaan dengan pluralitas pandangan dalam Islam yang dogmatis dalam fundamental Islam. prinsip. "persatuan iman, keharmonisan khilafiyah," Satori menyebutnya sebagai teori. Sedangkan isu dan wacana khilafiyah banyak terjadi di masyarakat pedesaan dan disikapi dengan sikap yang positif. Jahar basmalah atau bukan, kunut atau bukan, idenya adalah, terlepas dari adat istiadat atau ritual dan nilai yang mereka miliki, orang berkewajiban untuk mematuhi imam.

Masyarakat pedesaan di Guwa Lor menekankan untuk tidak terlibat dalam konflik masalah yang tidak berprinsip namun untuk didiskusikan. Minimnya konsep keberagaman yang konsisten di bidang fiqih itu sendiri telah menyebabkan munculnya konflikkonflik yang serius hingga pada titik aktivitas yang parah, konfirmasi kolektif dan campur tangan anarkis. Secara teori, tokoh agama dan tokoh masyarakat desa Guwa Lor mengajarkan bahwa hukum sudah jelas namun pelaksanaanya harus berpegang teguh pada argumen etis jadi bukan hanya persoalan benar atau salah.

Tokohagamasecarategasdanobjektif dalam setiap pengajaran memberikan muatan agama Islam klasik melalui kajian taklim, dengan memberikan kebebasan kepada masyarakat untuk menilai dan memilih pendapat tersebut. Ini, pada gilirannya, memberikan penghargaan pedagogis untuk mendorong sikap menuju kedewasaan dan kesediaan menerima perbedaan. Masyarakat tidak diindoktrinasi, untuk sepenuhnya 
mendukung satu pandangan, tanpa pengawasan kritis. Jadi, meski harus memilih tradisi atau pengalaman sebagai panutan, masyarakat tidak dipaksa untuk menantang nilai-nilai konvensional atau praktik mereka sendiri dengan syarat ada alasan yang lebih meyakinkan.

Budaya toleransi masyarakat pedesaan di Guwa Lor, mempertimbangkan pluralitas berdasarkan pandangan ulama terhadap suatu hal, Kiai menggali asal mula masalah dan alasan perbedaan pendapat yang diikuti dengan klaim masing-masing, kemudian secara objektif menganalisisnya untuk menemukan suatu pendapat atau konsensus yang lebih kuat antara pandangan yang berlawanan. Seperti yang dikatakan Irwan, konsep ini akan membawa masyarakat menjadi mujtahid untuk dirinya sendiri, bukan mujtahid absolut untuk orang lain (wawancara dengan Irwan, 23 April 2020).

dan $\begin{array}{rlr}\text { Internalisasi } & \text { konsep } & \text { toleransi } \\ \text { penciptaan } & \text { identitas } & \text { muslim }\end{array}$ moderat di kalangan pendidikan yang diselenggarakan di masyarakat pedesaan Guwa Lor. Mereka menggunakan nalar dan logika yang logis dalam ajaran ini untuk menjelaskan interpretasi ajaran agama sambil menjaga konsistensi dengan nilai-nilai Islam secara umum. Pengajaran seperti itu juga membantu masyarakat untuk menciptakan cara pandang dan pemahaman yang holistik dalam menafsirkan makna Islam, melatih daya kritis, dan mengembangkan model religiusitas yang plural, logis, tidak kaku, dan dogmatis.

Berpegang pada satu sudut pandang dan mengedepankan sesuatu selain kecenderungan umum masyarakat, budaya tidak ditekankan sebagai fanatik dan irasional. Jika mereka lebih fokus pada pelestarian nilai-nilai tradisional atau aktivitas mereka secara umum, maka mereka berusaha untuk mewakili mereka secara hormat dengan menyuarakan semua pendapat sebagaimana adanya.
Hasil dari pergulatan teoretis yang intens antara pemuka agama dan pemuka masyarakat ini mampu menjawab persoalan real dalam kehidupan mereka. Ada kasus yang diselesaikan kemudian, dan ada yang masih disengketakan. Demikian juga, hal itu menghasilkan hipotesis. Dengan demikian, manusia dan siapa pun yang mempelajari agama harus mengikuti cara atau pemikiran para pendahulu, dan tidak hanya mengandalkan hasil studinya.

Bagaimanapun, itu tidak lain adalah hasil refleksi manusia atas teksteks agama yang diciptakan untuk merefleksikan pola yang mendasari beberapa metode. Ia tidak dapat diisolasi dari ruang dan waktu, sebagai akibat dari kognisi manusia. Dengan kata lain; produk dialog dengan fakta sejarah. Hasilnya juga dapat berbeda dari orang ke orang, dari waktu ke waktu dan dari ruang ke ruang. Melalui studi dan taklim yang diadakan di masjid atau jamur Tuhan dan lokasi lain, ide dan konsep ini diinternalisasikan ke publik oleh para pemimpin agama; intinya, menghasilkan Muslim yang multikultural, moderat, beragam dan vital, bukan Muslim yang kolot, statis, eksklusif dan menolak realitas majemuk.

Tokoh masyarakat di Guwa Lor seringkali mengadopsi pendekatan pluralistik dalam kaitannya dengan hubungan sosio-pedagogis. Upaya membentuk pola pikir dan sikap pluralistik pada masyarakat pedesaan tersebut dilakukan dengan memberikan hak kepada masyarakat untuk menyampaikan pendapat; mendorong masyarakat untuk mempertimbangkan pandangan orang lain, dan mengajak masyarakat untuk berdialog, terutama dengan pihak-pihak yang berbeda pemahaman tentang mereka. Debat ini tidak dilakukan untuk menimbulkan kontroversi, perdebatan yang memanas, membangkitkan egoisme secara 
emosional tetapi untuk mendorong publik untuk mempertimbangkan dan menghormati mereka yang berbeda pendapat.

Ikatan sosial kemasyarakatan di Guwa Lor yang kental dengan kompleksitas namun tetap menawarkan cara hidup dan cara pandang yang plural, tanpa menimbulkan ketegangan di antara mereka sendiri berdasarkan perbedaan pemahaman keagamaan, menurut penuturan Nasirudin sebagai pemuka agama dan pendidik, perbedaan suku, latar belakang keluarga, dan status sosial sering kali menciptakan ketimpangan sosial di antara mereka, namun di sisi lain menciptakan dinamika intelektual dalam diskusi ilmiah tentang masalah hukum, sosial, dan ekonomi (wawancara dengan Nasirudin, 24 April 2020).

Hasil observasi dan penelusuran data di atas menunjukkan bahwa masyarakat pedesaan di Guwa Lor telah menginternalisasi konsep pluralisme sosial melalui tiga jaringan, yaitu: pluralisme yang dikembangkan melalui gagasan dan pemikiran tokoh agama dan tokoh masyarakat. Kehidupan dan budaya adalah cara yang ampuh untuk menanamkan ide ini. Tentu saja, yang membantu kandidat untuk disetujui adalah dengan mengadvokasi nilai-nilai bersama, kebijakan dan pencegahan baik di tingkat formal maupun non-formal. Kesepakatan sosial yang diberikan dibatasi pada dua poin kunci yaitu pemahaman agama dan akhlak mulia dalam sikap, aktivitas, perbuatan, dan interaksi sehari-hari.

Pemahaman yang matang terhadap agama dipandang sebagai upaya untuk memahami secara penuh dan mendalam serta menguasai ilmu-ilmu agama beserta cabang dan metode studinya. Penguasaan ilmu agama yang mendalam akan membuka wawasan seluas-luasnya, menghindari kepicikan, subjektivitas, dan klaim fakta tentang nilai atau tindakan atau perilaku tertentu yang mendorong orang untuk berpikir secara metodologis dan kritis dalam memahami atau menemukan jawaban atas masalah sosial. Namun tidak terjebak dalam fanatisme tidak sehat, meski masih dalam kategori ijtihad, orang bisa melakukan ijtihad sendiri-sendiri, namun tidak untuk dipaksakan pada orang lain.

Masyarakat pedesaan di Guwa lor dengan kesadaran sendiri menanamkan dan mengembangkan sikap toleran, dengan memasyarakatkan dan mengintegrasikan nilai-nilai pluralisme agama ke dalam kehidupan sehari-hari. Keberadaan komunitas dalam ranah kehidupan sesama budaya yang majemuk dan relatif heterogeny, memfasilitasi terciptanya suasana sosial yang inklusif baik dari segi budaya, tradisi, bahasa, pola pikir, latar belakang sosial dan ekonomi, serta memberikan implikasi sosio-psikologis bagi pembentukan sikap empatik terhadap adanya perbedaan.

Keyakinan dan wibawah pemimpin masyarakat dipandang berhasil mendobrak hambatan sosial dan budaya dalam membangun jaringan persahabatan dan hidup damai. Untuk itu, mereka menekankan pada pengajaran dan penerapan nilai-nilai moral, serta pengembangan ilmu-ilmu Islam; pengetahuan dan moralitas menjadi alat kontrol sosial yang dipadukan, tidak terpisah dan diabaikan para pemimpin agama dan budaya.

Pengajian, taklim, mingguan atau pasaran menjadi pendekatan dialogis, kritis, dan terbuka, tanpa upaya dogmatis untuk memaksakan doktrin dan pandangan tertentu. Buku dan menteri pengajar tersebut disampaikan dengan menyuarakan berbagai jenis tafsir dan memberikan keleluasaan publik dalam memilih opini terbaik. Dalam masyarakat pedesaan Guwa Lor sendiri merupakan campuran atau kombinasi dari berbagai ritual atau adat istiadat dan 
mazhab pemikiran. Ajaran agama dalam masyarakat pedesaan tidak melegitimasi dan membenarkan kegiatan atau tradisi tertentu tetapi budaya itu sendiri yang disesuaikan dengan agama.

Penerapankonsepinternalisasi pada dasarnya dirancang untuk menanamkan prinsip kemajemukan dan membentuk sikap empati terhadap individu lain. Internalisasi filosofi pluralisme yang berupaya membentuk sikap empati dicapai melalui penerapan nilai-nilai moral, penciptaan budaya hidup yang inklusif dan pengajaran untuk mau menerima kritik. Internalisasi ini dicirikan sebagai upaya untuk memasukkan, menanamkan, dan mengintegrasikan nilai-nilai dalam suatu entitas sehingga menjadi karakter dan pola dasar bagi keyakinan dan pandangannya; ada formasi pribadi yang pluralistik dan empatik; ia menerima tidak hanya perbedaan tetapi juga berpartisipasi dalam penciptaan perdamaian dan kehidupan keagamaan yang inklusif.

Berawal dari hasil observasi di atas, terbukti bahwa masyarakat pedesaan bukanlah masyarakat yang solid, radikal, kaku, picik, dan tidak mau menerima kebenaran dari orang lain. Nasirudin, seorang pemuka agama di Guwa Lor, dan seorang guru agama setuju. Masyarakat, dalam pandangannya, "masyarakat yang demokratis dan terbuka. Konsekuensinya, internalisasi nilai-nilai sosial, seperti pluralisme menjadi mentalitas atau pemahaman untuk mencapai kebaikan bersama, sangat mudah diterima dan diintegrasikan ke dalam kehidupan sehari-hari mereka." (wawancara dengan Nasirudin, 21 April 2020).

Perspektif sosiologis, ada kemungkinan yang disebut pluralismedogmatis, bukan pluralisme terapan, di masyarakat pedesaan, khususnya di Guwa Lor. Yakni kemajemukan yang ada hanya karena sosok kiai yang pluralistik, sehingga mereka beranggapan harus menganut filosofi pluralis kiai. Dengan demikian, masyarakat merangkul dan mempromosikan pluralism agama yang tidak murni, baik karena pemahaman mereka sendiri tentang kebutuhan akan cita-cita ini atau karena pengalaman yang telah mereka pelajari dan amati sendiri. "Upaya penyadaran datang dari masyarakat sendiri," kata Muslim. "Ini terletak pada pentingnya kontak interpersonal dalam masyarakat pedesaan yang lebih demokratis dan pluralistik, yang lebih akrab dengan halhal di luar keyakinannya." (wawancara dengan Muslim, 21 April 2020).

Hasil pengamatan penulis, masyarakat pedesaan di Guwa Lor memiliki potensi dan ruang lingkup sosial budaya untuk mendorong pemahaman pluralis. Dari praktik ritual keagamaan masyarakat pedesaan tersebut, dapat dirumuskan model toleransi yang mengakomodir gagasan pluralisme sebagai dasar pembentukan paradigma masyarakat harmoni. Model toleransi sebagai hasil interaksi pluralistik di masyarakat pedesaan sangat dipengaruhi oleh gagasan dan wawasan tokoh masyarakat dan kiai; terbentuk secara alamiah melalui keteladanan dalam bermasyarakat dan nilai-nilai kemajemukan.

Terbentuknya solidaritas, persaudaraan dan komitmen pada masyarakat pedesaan di Guwa Lor merupakan modal tersendiri untuk nilai-nilai toleransi. Pada struktur sosial masyarakat pedesaan membantu proses transformasi sikap dan nilai-nilai religius, masyarakat pedesaan tumbuh menjadi institusi sosial dengan struktur dan budaya yang unik, membentuk sistem komunikasi interpersonal, mendukung dan membantu mewujudkan prinsip-prinsip umum yang mereka impikan dalam komunitas terbatas. 


\section{SIMPULAN}

Praktik ritual keagamaan yang ada di masyarakat pedesaan saling memberikan ruang terbuka untuk saling mengenal dan memahami aliran atau paham yang berbeda, sehingga timbul kesedian masyarakat menjadi pribadi yang terbuka, mudah bergauldengan yang berbeda pemahaman dan menumbuhkan persamaan identitas religius. Toleransi beragama yang terjadi di masyarakat pedesaan tidak sepenuhnya mengubah keyakinan atau paham aliran orang lain melainkan mereka tetap pada suatu keyakinan yang diyakini kebenarannya, sehingga ketika itu terjadi bukan karena paksaan namun timbul karena kerelaan sendir. Sikap toleran mereka tidak hanya akan sebatas basa-basi tanpa menafikan ajaran agama dan berakulturasi dengan nilai kemanusiaan yang muncul di masyarakat. Masyarakat memahami perbedaan paham keagamaan secara rasional, irasional bahkan mistis sehingga mengakibatkan adanya heterogenitas pemahaman dalam ritual keagamaaan. Apa yang dituturkan ini kadang bisa menimbulkan konflik namun dengan kehadiran tokoh agama yang pluralis karismatik mampu memberikan pemahaman bahwa adanya perbedaan dalam praktik ibadah memberikan kemudahan dan keseimbangan kohesi sosial masyarakat sehingga menumbuhkan sikap toleran dalam beragama melalui ragam perbedaan tersebut.

\section{SARAN/REKOMENDASI}

Penelitian ini masih jauh dari memadai untuk menggambarkan dinamika praktik keagamaan yang terjadi di masyarakat pedesaan khususnya tentang toleransi pada ragam budaya dan adat masyarakat di pedesaan, untuk memberikan ruang tersebut pemerintah khususnya harus hadir menjaga kerukunan hidup beragama dengan memberikan ruang dialog dan kemungkinan-kemungkinan lain yang bisa ditempuh.

\section{UCAPAN TERIMA KASIH}

Rasa terima kasih yang sangat mendalam kami sampaikan pada Dewan Redakasi Jurnal Harmoni Puslitbang Bimas Agama dan Layanan Keagamaan Kementerian Agama yang telah memberikan kesempatan kepada penulis menjadi kontributor dalam edisi terbitan ini serta kepada para reviewer yang telah memberikan masukan bermanfaat untuk perbaikan artikel. Terima kasih pula untuk semua pihak yang telah membantu dalam proses penulisan yang tidak bisa penulis sebutkan satu persatu, khususnya untuk teman-teman mahasiswa studi Agama-Agama Institut Agama Islam Negeri Sunan Gunung Djati Bandung beserta dosen, staf dan jajarannya. 


\section{DAFTAR ACUAN}

Abdullah, M. A. (2011). Hak Kebebasan Beragama dan berkeyakinan: Pendekatan Filsafat Sistem dalam Usul Fikih Sosial. Salam: jurnal studi Masyarakat Islam, Vol. 14.

Ali, A. (2007). Agama dalam Ilmu Perbandingan Agama. Nuansa Aulia.

Arifin. dkk., S. (2004). Pluralisme Keagamaan di Pedesaan: Studi Tentang Pola Interaksi Sosial Tiga Kelompok Agama (Islam, Kristen dan Budha) di Mojorejo Batu. Ditjen Bagais Depag RI.

Arikunto, S. (2002). Prosedur Penelitian Suatu Pendekatan Praktek. Rineka Putra Cipta.

Arwani, W. (2014). Kiai Pesantren dan Kontribusinya dalam Mengembangkan Pluralitas Keberagamaan dan Toleransi di Kabupaten Cirebon. Holistik:Jurnal for Islamic Social Sciences, Vol. 15.

Azra, A. (1999). Konteks Berteologi di Indonesia: Pengalaman Islam. Paramadina.

Badan Pusat Statistik. (2016). Kabupaten Cirebon dalam Angka. BPS Kab. Cirebon.

Badan Pusat Statistik. (2019). Kabupaten Cirebon dalam Angka Cirebon. BPS Kab. Cirebon.

Baharudin, M., \& Luthfan, M. A. (2017). The Transcendent Unity Behind the Diversity of Religions and Religiosity in the Perspective of Perennial Philosophy and Its Relevance to the Indonesian Context. Walisongo: Jurnal Penelitian Sosial Keagamaan, Vol. 25.

Beatty, A. (2003). Varietiesof Javanese Religion; An Anthropological Account. Cambridge University Press.

Beuken, W., \& Kuschel. (2003). Agama Sebagai Sumber kekerasan? (terj.) Imam Baehaqi. Pustaka Pelajar.

Dhohiri, T. R. (2003). Sosiologi Suatu Kajian Kehidupan Masyarakat. Yudistira.

Fatoni, A. (2020). Memaknai Kekerasan Orang Madura di Perantauan: Studi Sosial Keberagamaan Masyarakat Madura di Semampir Jawa Timur. Harmoni: Jurnal Multikultural dan Multireligius, Vol. 19.

Fromm, E. (2004). Akar Kekerasan: Analisis Sosio Psikologis atas Watak Manusia (terj.) Imam Muttaqin. Pustaka Pelajar.

Geertz, C. (1983). Abangan Santri Priyayi Dalam Masyarakat Jawa. Pustaka Pelajar.

Haryani, E. (2019). Intoleransi dan Resistensi Masyarakat Terhadap Kemajemukan: Studi Kasus Kerukunan Beragama di Kota Bogor Jawa Barat. Harmoni: Jurnal Multikultural dan Multireligius, Vol. 18.

Hasyim, S. (2015). Majelis Ulama Indonesia and pluralism in Indonesia. Philosophy \& Social Criticism, Vol. 2.

Hefner, R. W. (1987). Islamizing Java? Religion and Politics in Rural East Java. The Journal of Asian Studies, Vol. 46.

Hefner, R. W. (2000). Mengislamkan Jawa? dalam Islam Pasar Keadilan Artikulasi Lokal Kapitalisme dan Demokrasi, terj,. Aminudin. LKiS.

Imarah, M. (1999). Islam dan Pluralitas. Gema Insani Press.

\begin{tabular}{l|l} 
HARMONI & Juli - Desember 2020
\end{tabular} 
Iswanto, \& Hasiholan Hutapea, R. (2019). Lego-Lego sebagai Simbol antaragama dan Budaya di Masyarakat Alor. Harmoni: Jurnal Multikultural dan Multireligius, Vol. 19.

Jamil, M. M. (2007). Mengelolah Konflik Membangun Damai. Walisongo Media Centre.

Juergensmeyer, M. (2008). Menentang Negara Sekuler: Kebangkitan Global Nasionalisme Religius, terj., Noorhaidi. Mizan.

Knitter, P. F. (1985). No Other Name? A Critical Survey of Christian Attitudes Toward the World Religions. Orbis Books.

Kuntowijoyo. (1993). Paradigma Islam Interpretasi untuk Aksi. Mizan.

M. Setiadi, E., \& Kolip, U. (2013). Pengantar Sosiologi Pemahaman Fakta dan Gejala Permasalahan Sosial: Teori, Aplikasi dan Pemecahannya. Prenamedia Group.

Majelis Ulama Indonesia. (2005). Fatwah MUI tentang Pluralisme Liberalisme dan Sekularisme Agama. mui.or.id.

Maknun, M. L. (2020). Kontestasi Kerukunan Umat Beragama di Kaki Pura Arga Sunya. Harmoni: Jurnal Multikultural dan Multireligius, Vol. 19.

Moleong, L. J. (2007). Metode Penelitian Kualitatif. Remaja Rosdakarya.

Narbuko, C., \& Ahmadi, A. (2001). Metodologi Penelitian. Bumi Aksara.

Nawawi, H. (2007). Metode Penelitian Bidang Sosial. UGM Press.

Nugroho, M. A. (2016). Urgensi dan Signifikansi Pendidikan Islam Multikultural Terhadap Kompleksitas Keberagamaan di Indonesia. at Tarbiyah: Jurnal of Islamic and Education, Vol. 1.

Panuntun, D. F., \& Paramita, E. (2020). Hospitalitas Kristen dan Tantangannya di Tengah Pandemi Covid-19. Harmoni: Jurnal Multikultural dan Multireligius, Vol. 19.

Perdue, W. D. (1986). Sosiological Theory: Explanation Paradigm and Ideology. Mayfield Publishing Company.

Ridho, A. (2018). Spiritualitas Pencari Kemebuhan Studi Atas landasan Teologis Wisatawan di Obyek Wisata Banyu Panas Gempol Palimanan. Harmoni: Jurnal Multikultural dan Multireligius, Vol. 2.

Ridho, A. (2019). Pesan Moral dalam Puisi “Padamu Jua” Karya Amir Hamzah. Madah: Jurnal Bahasa dan Sastra, Vol. 1.

Ritzer, G. (2004). Sosiologi Ilmu Pengetahuan Berparadigma Ganda. Raja Grafindo Persada.

Rohman, A. (2016). Pluralism Based Religious Education for Deradicalization of Religion. al Ulum, Vol. 16.

Saihu. (2020). Harmoni Hindu-Muslim di Bali Melalui Kearifan Lokal: Studi di Kabupaten Jembrana. Harmoni: Jurnal Multikultural dan Multireligius, Vol. 19.

Scharf, B. R. (1995). Kajian Sosiologi Agama, terj., Machnun Husein. Tiara Wacana.

Scharf, B. R. (2004). Sosiologi Agama. Kencana.

Setiawan, I. (2019). Sepanjang 2019 Imparsial sebut 31 kasus intoleransi di Indonesia. GATRA. 
https://www.gatra.com/detail/news/457157/politik/sepanjang-2019-imparsialsebut-31-kasus-intoleransi-di-indonesia

Setyabudi, M. N. P. (2019). Memperlebar Batas Toleransi dan Membela Hak Minoritas. Harmoni: Jurnal Multikultural dan Multireligius, Vol. 17.

Situmorang, V. H. (2019). Kebebasan Beragama Sebagai Bagian dari Hak Asasi Manusia. Penelitian HAM, Vol. 10.

Sugiono. (2005). Memahami Penelitian Kualitatif. Alfabeta.

Sumbulah, U. (2015). Pluralisme dan Kerukunan Umat Beragama Perspektif Elite Agama Di Kota Malang. Analisa: Journal of Social Science, Vol. 2.

The Wahid, I. (2014). Laporan Tahunan Kebebasan Beragama/Berkeyakinan Dan Intoleransi 2014 Utang Warisan Pemerintah Baru. The Wahid Institut.

Umam, K., \& Ghazali, A. M. (2019). Pandangan Tokoh Agama di Karesidenan Cirebon dalam Memandang Pluralitas Beragama. Nuansa Jurnal Penelitian Ilmu Sosial dan Keagamaan Islam, Vol. 16.

Wardah, F. (2019). Pelanggaran Kebebasan Beragama di Indonesia Meningkat. VOA Indonesia. https://www.voaindonesia.com/a/pelanggaran-kebebasan-beragamameningkat-/3203566.html

Watloly, A. (2001). Tanggung Jawab Pengetahuan: Mempertimbangkan Epistemologi Secara Kultural. Kanisius.

Woodward, M. R. (1988). Islam in Java: Normative Piety and Mysticism in the Sultanate of Yogyakarta. UMI.

Wrong, D. (2003). Max Weber Sebuah Khazanah, terj., A. Asnawi. Ikon Teralitera.

Zakiyuddin. (2002). Ambivalensi Agama: Konflik dan Nirkekerasan. Lesfi. 